SCIREA Journal of Health

http://www.scirea.org/journal/PMH

November 16, 2021

Volume 5, Issue 6, December 2021

\title{
Reviewing Ernest Everett Just's BIOLOGY OF THE CELL SURFACE (1939) and related literature, plus annotated references,
}

\section{hereby advancing evolutionary biology and evolutionary bioethics}

Theodore Walker Jr.

Southern Methodist University, Dallas Texas USA

Email: twalker@smu.edu

\begin{abstract}
:
The Biology of the Cell Surface (1939a) by Ernest Everett Just is focused on marine egg cells and egg cell surfaces. By studying egg cells, and cell surface mediated co-operation with sperm and environment, E. E. Just advanced egg cell fertilization and developmental biology, including embryo morphogenesis, ecological developmental (eco-devo) biology, and theory of evolution. According to Just, from cells to humans, development and evolution require cooperative behavior. In developmental biology, Just observed that co-operative behavior is essential to animal development from a single egg cell. In evolutionary biology, Just reasoned that co-operative behavior is essential to evolution from our common unicellular ancestor. And in evolutionary bioethics, Just tied evolutionary biology to evolutionary ethics by reference to evolution from a common unicellular ancestor with cell surface mediated cooperative interactions with the environment. In accordance with the "law of environmental dependence," evolutionary bioethics must also be environmental bioethics. Even though E. E.
\end{abstract}


Just may have overestimated cell surface influences, he correctly estimated the developmental potence and the evolutionary potence of the whole living cell interacting co-operatively with its life-inspiring environment.

Keywords: Stammzell, stem cell, common unicellular ancestor, egg cell, cell surface behavior, interaction, co-operation, social instinct, developmental biology, evolutionary biology, evolutionary ethics, evolutionary bioethics, law of environmental dependence, environmental bioethics.

The idea of linking evolutionary biology to evolutionary ethics by reference to evolution from a common unicellular ancestor with cell surface mediated co-operative interactions with the environment was advanced in The Biology of the Cell Surface (1939a) by Ernest Everett Just (1883-1941).

For a book on "the biology of the cell surface" to have on its title page Goethe's Latin —Natur hat weder Kern Noch Schale, Alles ist sie sie mit einemmale (Nature has neither core nor shell, It is everything at once) signals that the cell surface is not a "mere protective and nutritive shell" (Just 1939a: 8). More than a mere inert shell, ectoplasmic behavior indicates that the ectoplasm is a "living part of the living system" (Just 1939a: 71; 78, 103, 104, 123), that "the cell-surface is living ectoplasm, continuous with the remainder of the protoplasm" (Just 1939a: 142; 146). Rather than life residing in either core or shell, E. E. Just held that life is "not confined to nucleus only and certainly not to constituent genes," and not confined to ectoplasm alone. Instead, for cells, the "state of being alive" is about integrating "the whole of the protoplasmic system taken as a unit" interacting with environment (Just 1939a: 363). Throughout Biology of the Cell Surface (1939a), "neither core nor shell ..." is a fundamental principle.

In practice, however, E. E. Just's light microscope allowed seeing shell events, such as the "clearly visible" "propagation of the effect of sperm-attachment over the surface of the egg" (Just 1939a: 116) and "cell cleavage," but not core events invisible to light microscopes, such as DNA replication. By observing clearly visible ectoplasmic events, "we witness the expression of activities that set apart the living thing from the non-living, that mark how life maintains itself ever in harmonious tempo with the ceaseless changes in its surroundings" (Just 1939a: 103), and we see "manifestations of the state of being alive" (Just 1939a: 104). 
Given the "observation selection effect" (Bostrom 2002) of viewing shell-not-core via light microscopes, E. E. Just's observation-based "theory of the ectoplasm" (1939a: 365-369) included corresponding overestimates of ectoplasmic influences.

Examples of overestimating shell influences (relative to core and whole unit influences) include the following:

"For animal cells, generally, we must seek the cause of cell-division in ectoplasmic activity" (Just 1939a: 285).

"My fundamental thesis is that all the differences, i.e., differentiation, that appear during development, rest upon cytoplasmic reactions" (Just 1939a: 326).

"... it is this potency in the cytoplasm which determines the future growth and differentiation of the egg to that moment ..." (Just 1939a: 329).

"Ectoplasmic behavior" is "so far the only visible manifestation of the cause of the differentiation of development which takes place during cleavage" (Just 1939a: 339).

[Italics added to emphasize estimates corresponding to light microscope limits.]

Ectoplasmic changes always "come first" and "the magnitude of the ectoplasmic changes determines that of the nuclear" (Just 1939a: 340).

"... in ectoplasmic behavior lies the cause of the behavior of the chromosomes" (Just 1939a: $352)$.

"Thus all forms of behavior by which we recognize that a thing is alive express themselves in response to the environment in the activity either of the ectoplasm itself - as in unicellular organisms — or of structures which are rich in ectoplasm" (Just 1939a: 360).

"Then species arose through changes in the structure and behavior of the ectoplasm" and we must seek "the cause of evolution" in "the differentiation of ectoplasm from the groundsubstance" (Just 1939a: 361).

Nevertheless, overestimates or not, during the 1920s and 1930s E. E. Just became the internationally acknowledged authority on marine egg cell fertilization by describing blocks to polyspermy, cell cleavage and early embryo development (Just 1919a, 1919b, 1919c, 1920, 1921, 1922a, 1922b, 1922c, 1932, 1933, 1937, 1939a), and by teaching (first MBL researchers, then others) Basic Methods for Experiments on Eggs of Marine Animals (Just 1939b). 


\section{Any Living Thing and Environment}

In The Biology of the Cell Surface (Just 1939a), beyond describing marine animal eggs, fertilization, and early embryo development (pages 1-339) as "visible expressions" of ectoplasmic interactivities (1939a: 363), E. E. Just added theoretical deliberations (pages 340369). This addition is justified because descriptive cell surface biology "embodies principles which concern the fundamental organization of any living thing" (Just 1939a: ix-x).

Concerning the structure and behavior of "any living thing," E. E. Just says: "A living thing is not only structure but structure in motion ... a moving event ... Life is exquisitely a timething like music ..." and "any living thing" is more than the sum of its parts, more than "the sum-total of the multitudinous chemical components in an agglomerate mass" and a "living thing represents in its unit of structure and behavior the highest order of complexity in nature" (Just 1939a: 2-3).

Concerning any living thing interacting with its environment, E. E. Just says that "cells alone and as members of a unit-system exhibit different behaviors" (Just 1939a: 34), that "cells in tissue-culture are no longer under the restraint imposed upon them when they stand in coordination with and subordination to their normal environment" (Just 1939a: 86), and that "an organism or cell has a dependent relation to its environment" (Just 1939a: 226).

\section{Abiogenesis and Environment}

According to E. E. Just, at whatever moment life first arose "out of non-living matter" (the cause of which Just does not attempt to explain), it first arose in interactivity with the environment. From the very first moment, life "must have been responsive to environmental changes" (Just 1939a: 355). Furthermore: "Environmental changes must in the first instance have brought about the combinations of compounds peculiar to living substance, and in the second place must have conditioned its activity" (Just 1939a: 355). A living thing or organism, says Just, "cannot be separated from its environment, they form together one inter-acting system ... we should not speak of the 'fitness of the environment' or the 'fitness of the organism'; rather, we should regard organism and environment as mutually adapted" (Just 1939a: 356-357). From the beginning, life and environment must co-operate. 


\section{Co-operative Behavior}

Concerning living thing and co-operative behavior in developmental biology, and in theory of evolution, E. E. Just says:

"The living thing is part of the natural world ... living thing and outside world constitute one interdependent unity, as evolution teaches, as the development of an animal egg reveals" (Just 1939a: 366).

"Life is not only a struggle against the surroundings from which life came; it is also a cooperation with them. The Kropotkin theory of mutual aid and co-operation may be a better explanation of the cause of evolution than the prevailing popular conception of Darwin's idea of the struggle for existence. The means of co-operation and adjustment is the ectoplasm...."

(Just 1939a: 367)

Instead of conceiving that evolution is driven exclusively or mostly by competitive "struggle against" others and against the surrounding environment (a popular conception of Darwin), in Mutual Aid: A Factor of Evolution (1902) Peter Kropotkin argued that, for evolution, "mutual aid" or "co-operation" is essential. Then, to various zoological observations made by Darwin, Kropotkin, and many others, E. E. Just added microscope observations of cellular cooperative behavior.

Adding microscope observations is important because, without such observations, "evidence is insufficient to warrant the hypothesis that sociality parallels the course of evolution" (Just and Just 1941: 240). By adding observations of co-operative behavior among cells, and paralleling the evolution of human bodies from cells, the evolution of human ethical behavior is "carried farther back than heretofore," carried back to "the first link of the chain" (Just and Just 1941: 248, 251), to cellular origins! In parallel with the evolution of human physiology, human ethical behavior evolved from cellular origins. Accordingly, The Biology of the Cell Surface (1939a) was followed by The Origin of Man's Ethical Behavior (Unpublished 1941 book manuscript [published in 2020]) by Ernest Everett Just and Hedwig Schnetzler Just. 


\section{Developmental Biology, Evolutionary Biology, and Evolutionary Bioethics, including Environmental Bioethics}

E. E. Just offered new observational data and original deliberations (reasonings) that advanced cell and developmental biology, including embryo morphogenesis, ecological developmental (eco-devo) biology, and developmental evolution. Furthermore, E. E. Just advanced general theory of evolutionary biology including evolutionary ethics or evolutionary bioethics and environmental bioethics.

Concerning animal development from an egg cell, E. E. Just wrote:

"Only in the egg and its development can we hope to trace to its source the pattern of structure and to resolve into its motif the harmonious behavior which characterizes the manycelled animals"

(Just 1939a: 19).

Development from an egg cell into a many-celled adult requires "harmonious behavior" (Just 1939a: 19) among cells interacting with other cells and the environment. Similarly, concerning the whole of Earthly evolution from a unicellular ancestor, Just wrote:

"The history of the multicellular organism as it develops from the egg, a single cell, to the adult is very much like a synopsis of the history of the whole world of multicellular organisms, this has most probably evolved from a single cell ancestor" (Just 1939a: 36).

"Among biologists exists the almost unanimous verdict that evolution took place. According to the prevailing opinion, the world of living things was evolved from a unicellular organism" (Just 1939a: 354).

In developmental biology, E. E. Just observed that co-operative behavior is essential to animal development from a single cell, an egg cell.

In evolutionary biology, E. E. Just reasoned that co-operative behavior is essential to evolution from a single cell ancestor. This unicellular ancestor, from which evolved "the whole world of multicellular organisms" (Just 1939a: 36), is the original "Stammzell" (stem cell) from which "all multicellular organisms evolved" (Haeckel, 1868, Haeckel, 1874; Wilson 1896). In "On the Origin of the Term 'Stem Cell”" (7 June 2007) Miguel RamalhoSantos and Holger Willenbring report that in 1868 German biologist Ernst Haeckel used the term "Stammzell" to refer to our common unicellular ancestor; and in 1874 Haeckel used "Stammzell" to refer to both unicellular ancestor and fertilized eggs. 
In evolutionary bioethics, and with no use of the phrase "evolutionary bioethics" (Potter 1984) and no use of the word "bioethics" (Potter 1971), E. E. Just tied evolutionary biology to evolutionary ethics by reference to evolution from a cell ancestor with cell surface mediated co-operative interactions with its environment. In accordance with the "law of environmental dependence" (Just and Just 1941: 5, 157-168, 174), necessarily, evolutionary bioethics must also be environmental bioethics.

According to Ernest Everett Just and Hedwig Schnetzler Just, evolution "from a single cell ancestor" (Just 1939a: 36) with cell surface mediated co-operative behavior and an inspiredspiritual "social instinct" (Just and Just 1941: 248-250) is essential to the "origin of man's corporeal being" and essential to the "origin of man's ethical behavior" (Just and Just 1941: 6; 133). Both human physical structure and human ethical behavior evolved from the physical structure and co-operative behavior (co-operative with environment) of a single cell ancestor. Here then is "a richer account of evolution" (Cobb 2008; also 1988).

\section{Evolutionary Astrobiology and Cosmology}

This biological narrative - about the origin, development, and evolution of living structures and behaviors, with biological evolution tied to "social evolution" (Denning 2009) and "cultural evolution" in "cosmic context" (Dick and Lupisella 2009)—resembles astronomical and cosmological narratives. According to evolutionary astrobiology and cosmology (Tyson and Goldsmith 2004; Casuso and Backman 5 October 2019), we are inspired and evolved stardust. The heavy elements, including carbon, evolved from previous generations of stars (Hoyle 1947; Burbidge, Burbidge, Fowler, Hoyle [ $\left.B^{2} F H\right]$ October 1957) that evolved from a finely tuned expanding universe (Hoyle 5 February 1949; Hoyle and Wickramasinghe 1981).

Similarly, connecting evolutionary egg cell biology to cosmology, E. E. Just wrote:

"The egg cell also is a universe. ... The sundering of the egg into many parts, to be woven again into a whole is no less wonderful than the breaking up of the primeval unit out of which the sun and the stars, the earth and the moon were made ..." (Just 1939a: 368).

Moreover, creation narratives from evolutionary biology and big bang cosmology, including astrobiology and "cosmic biology" (Wickramasinghe 2015), also resemble mythological creation narratives such as those described in "Creation from Chaos and from the Cosmic 
Egg" (chapter 3) in Alpha: The Myths of Creation (1963) by Charles H. Long, historian of religions.

\section{Contributions to Science}

E. E. Just made significant contributions to the history of science (Manning 1983, 16 July 2009; Jenkins 3 April 2021), including relatively well-known contributions and relatively unknown contributions.

Just's relatively well-known contributions include contributions to egg cell fertilization biology and developmental biology (Manning 1983; Byrnes 2009, 25 January 2010, December 2013, 24 June 2015; Byrnes and Eckberg 1 August 2006; Byrnes and others 20 August 2009; Katelyn M. Williams and others 18 July 2013; Byrnes and Newman June 2014; Mangal 2018; Byrnes 23 September 2019).

Just's relatively un-known contributions include contributions to "general biology" (Just, April 1940), evolutionary biology and evolutionary bioethics, including environmental bioethics (Manning 1983; Walker, January 2020, February 2020, 29 April 2020).

Ernest Everett Just (1883-1941) was ahead of his time. He foresaw that "cell surface" studies would be important for "applied biology" and treating medical problems (Just 1939a: 364; Grinnell, August 1975). Other examples of E. E. Just being ahead of his time include the following four clusters of pioneering ideas:

(1) E. E. Just advanced the idea that "an organism or cell has a dependent relation to its environment" (Just 1939a: 226) and generally, living things and environment are "mutually adapted," forming together "one inter-acting system" (Just 1939a: 356-357); and in accordance with the "law of environmental dependence" (Just and Just 1941: 5, 157-168, 174), life and environment must co-operate, co-create, and co-evolve. E. E. Just and H. S. Just advanced these ideas 33 to 35 years before the Gaia hypothesis (Lovelock 1972, Lovelock and Margulis 1974; also: Margulis 1981, 1993).

(2) E. E. Just connected evolutionary biology to human ethical behavior (Just 1939a: 367) and located ethics "within the field of biology" based on "theory of evolution" (Just and Just 1941: 3, 4, 9, 146). This 1939-1941 locating of ethics within biology came 30 to 32 years before the first book on "bioethics" (Potter 1971), 34 to 36 years before the father of sociobiology Edward O. Wilson prescribed " "that the time has come for ethics to be removed 
temporarily from the hands of philosophers and biologicized' (Wilson 1975: 27)" (Doris Schroeder, IEP), and 43 to 45 years before the father of bioethics Van Rensselaer Potter called for "evolutionary bioethics" (1984) with environmental emphasis.

*Today "bioethics" usually means human medical health care ethics. Originally, and literally, however, "bioethics" was "biology" plus "ethics" equals "bio-ethics" or "bioethics." And like the first book with "bioethics" as title-Bioethics: Bridge to the Future (1971) by Van Rensselaer Potter, and like Global Bioethics: Building on the Leopold Legacy (1988) by Van Rensselaer Potter, and unlike post-1971 exclusively human medical health care "biomedicine" (Brock 1984; Potter 1984), relations to the environment had been essential to the first article with "bio-ethics" as title-_Bio-Ethics: A Review of the Ethical Relationships of Humans to Animals and Plants" (1927) by Fritz Jahr (Sass, December 2007).

E. E. Just advanced the idea that co-operative behavior at the cellular level is essential to the origin, development, and evolution of life (Just 1939a; Just and Just 1941). This advance came 77 to 79 years before Scientific American reported the surprising [re-] discovery that microbes were co-operative team players, as indicated in "Team Players: Long thought mostly to compete with one another, microbes turn out to form partnerships that rule the planet" (November 2018) by Jeffrey Marlow and Rogier Braakman. Here, in November 2018, we see science starting to catch up to ideas advanced by Just during the 1930s.

E. E. Just's 1939 idea — that "life" is "a moving event," "a time-thing like music" (Just 1939a: 2-3, 9), "the harmonious organization of events, the resultant of a communion of structures and reactions" (Just 1939a: 7) —is fully resonant with the contemporary idea that "Every aspect of animal life-from morphology to physiology and behavior-requires the cooperation of thousands to billions of cells" and "cellular choreography" (Brunet and King 23 October 2017: Introduction; Brunet and King 5 November 2020 [also King, September 2004; Shah, Dey, and Dudin 5 January 2021; Aktipis 2020]) and that cells "coexist by cooperating" (Aktipis, January 2021).

These examples indicate that E. E. Just was so far ahead of his time that his work can help advance the contemporary search for general theories and fundamental principles of evolutionary biology and evolutionary bioethics, including environmental bioethics, and even astrobiology and cosmic biology. Also, the still newly developing search for "fundamental principles underlying stem cell behavior" (Lin 19 May 2020), including iPSC behavior, can be helped by correctly appreciating co-operative behavior in the origin, development, and evolution of life (stem cell behavior: Bains 2005; McCulloch and Till 1 October 2005; iPSC 
behavior: Kazutoshi and Yamanaka 25 August 2006; Yamanaka 14 June 2012; parthenogenesis: Just 1937).

It may be that in The Biology of the Cell Surface (1939a) Ernest Everett Just overestimated shell influences relative to core and whole unit influences, at times almost implying ectoplasmic "totipotence" (Burr, March 1939: 405). Nevertheless, E. E. Just correctly estimated both the developmental potence and the evolutionary potence of the whole living cell interacting co-operatively with its life-inspiring environment.

\section{References (with selected annotations and abstracts)}

[1] Aktipis, Athena. (2020). The Cheating Cell: How Evolution Helps Us Understand and Treat Cancer. Princeton University Press.

[2] Aktipis, Athena. (January 2021). "Malignant Cheaters: Cells coexist by cooperating. When some break the rules, cancers result" in Scientific American, volume 324, number 1, pages 62-67.

[3] Bains, Ajeet. (2005). "Perspectives on the Properties of Stem Cells" (2005) by Ernest McCulloch and James Till" in Embryo Project Encyclopedia (2020-06-30). ISSN: 19405030, http://embryo.asu.edu/handle/10776/13158. (Accessed 12 September 2021)

[4] Bostrom, Nick. (2002). Anthropic Bias: Observation Selection Effects in Science and Philosophy. New York: Routledge.

[5] Brunet, Thibaut, and Nicole King. (23 October 2017). "The Origin of Animal Multicellularity and Cell Differentiation" in Developmental Cell, volume 43, issue 2, pages 124-40, DOI:https://doi.org/10.1016/j.devcel.2017.09.016.

[Concerning the evolution and the origins of multicellularity, Brunet and King say: "The discontinuous phylogenetic distribution of multicellularity and differences in cellular mechanisms argue that multicellularity evolved independently in at least 16 different eukaryotic lineages ..." and "the mechanisms underpinning animal multicellularity and spatially controlled cell differentiation were likely elaborated in the stem lineage of animals, building upon pathways present in their single-celled ancestors ..." and "Despite the centrality of multicellularity and cell differentiation to animal biology, their origins are little understood" (Brunet and King 23 October 2017).]

[6] Brunet, Thibaut, and Nicole King. (5 November 2020). "The Single-Celled Ancestors of Animals: A History of Hypotheses.” Preprints 2020, 2020110302 
(doi:10.20944/preprints202011.0302.v1), online at

https://www.preprints.org/manuscript/202011.0302/v1 (Accessed 18 September 2021.)

[Abstract- "Animals, with their complex and obligate multicellularity, evolved from microbial eukaryotes that were likely obligately or facultatively unicellular. The nature of the unicellular progenitors of animals has intrigued biologists since the late $19^{\text {th }}$ century, coinciding with the parallel spread of the cell theory and the theory of evolution. However, views on the ancestry of animals have been extremely varied. The huge diversity of single-celled organisms, the tremendous plasticity of animal cellular phenotypes, and the difficulties of organizing both into clear phylogenies in the premolecular era allowed a wide range of hypotheses to flourish, with nearly every major single-celled lineage, at one time or another, having been proposed as the precursor of animals. Most of these hypotheses never gained followers beyond their originator (such as the ideas that animals evolved directly from either bacteria, Volvox or fungi) and will not be discussed here. Three concepts, however, have been enduring and influential: (1) the amoeboid theory; (2) the flagellate theory; and the (3) the ciliate theory - to which a fourth category can now be added: (4) a mixed model, in which the ancestor was phenotypically plastic. We will discuss their origin, history, and current relevance.”]

[7] Burbidge, E. Margaret with Geoffrey R. Burbidge, William A. Fowler, and Fred Hoyle. (October 1957). "Synthesis of the Elements in Stars" in Review of Modern Physics, volume 29, issue 4, pages 547-650 [doi:10.1103/RevModPhys.29.547].

[This work, signified by author initials as $B^{2} F H$, is so widely known among astronomers because it was "a turning point in our knowledge of how the universe works" (Neil de Grasse Tyson and Donald Goldsmith 2004: 165).]

[8] Burr, H. S. (March 1939). Book review of The Biology of the Cell Surface (Philadelphia: Blakiston's, 1939) by Ernest Everett Just, in the Yale Journal of Biology and Medicine (YJBM), 11(4): 405, PMCID: PMC2602111

[9] Byrnes, W. Malcolm. (2009). "Ernest Everett Just, Johannes Holtfreter, and the Origin of Certain Concepts in Embryo Morphogenesis" in Molecular Reproduction \& Development, 76: 912-921, online at http://europepmc.org/article/PMC/3371230.

[Abstract- "Ernest E. Just (1883-1941) is best known for his discovery of the "wave of negativity" that sweeps of the sea urchin egg during fertilization, and his elucidation of what are known as the fast and slow blocks to polyspermy. Just's contemporary Johannes Holtfreter (1901-1992) is known for his pioneering work in amphibian morphogenesis, which helped to lay the foundation for modern vertebrate developmental biology. This 
paper, after briefly describing the life and scientific contributions of Just, argues that his work and ideas strongly influenced two of the concepts for which Holtfreter is best known: tissue affinity and autoneuralization (or autoinduction). Specifically, this paper argues that, first, Just's experiments demonstrating developmental stage-specific changes in the adhesiveness of the blastomeres of cleavage embryos helped lay the foundation for Holtfreter's concept of tissue affinity and, second, Just's notion of the intrinsic irritability of the egg cell, which is evident in experimental parthenogenesis, strongly informed Holtfreter's concept of the nonspecific induction of neural tissue formation in amphibian gastrula ectoderm explants, a phenomenon known as autoinduction. Acknowledgment of these contributions by Just in no way diminishes the importance of Holtfreter's groundbreaking work. It does, however, extend the impact of Just's work into the area of embryo morphogenesis. It connects Just to Holtfreter and positions his work as an antecedent to embryo research that continues to this day."]

[10] Byrnes, W. Malcolm. (25 January 2010). "Ernest Everett Just: Experimental Biologist Par Excellence," via the American Society for Biochemistry and Molecular Biology, online at https://www.asbmb.org/asbmb-today/people/012510/ernest-everett-just. (Accessed 17 September 2021.)

[11] Byrnes, W. Malcolm. (December 2013). "The Genius of Ernest Everett Just" in Howard University Graduate School (HUGS) Research Magazine and Graduate School Research Archive, issue 002, online at https://www.researchgate.net/publication/259196977_The_Genius_of_Ernest_Everett_Ju st. (Accessed 17 September 2021.)

[Byrnes's opening paragraph says: "Ernest Everett Just (1883-1941) was a pioneering African-American embryologist who is best known for his discovery of the fast block to polyspermy, his elucidation of the slow block, and his discovery that the adhesive properties of the cells of the cleavage embryo depend on the particular developmental stage that they are in."] [accessed 15 December 2020].

[12] Byrnes, W. Malcolm. (24 June 2015). "E. E. Just and Creativity in Science: The Importance of Diversity" in Journal of African American Studies, (2015): 19:264-278. [DOI 10.1007/s12111-015-9305-1]. [(Dario Vargas, TC 8360, Summer 2020)]

[13] Byrnes, W. Malcolm. (23 September 2019). "E. E. Just's broad, yet hidden, influence on modern cell and developmental biology" in Molecular Reproduction and Development, https://doi.org/10.1002/mrd.23270. (Accessed 17 September 2021.) 
[14] Byrnes, W. Malcolm, and William R. Eckberg. (1 August 2006). "Ernest Everett Just (1883-1941) - An early ecological developmental biologist” in Developmental Biology, volume 296, issue 1, pp. 1-11, online at http://dx.doi.org/10.1016/j.ydbio.2006.04.445. (Accessed 17 September 2021.)

[15] Byrnes, W. Malcolm (Introduction) and others. (20 August 2009). Molecular Reproduction \& Development, volume 76, issue 10, October 2009 Special Issue: In Honor of E.E. Just

[16] Byrnes, W. Malcolm, and Stuart A. Newman. (June 2014 [Epub 24 March 2014]). "Ernest Everett Just: Egg and embryo as excitable systems" in the Journal of Experimental Zoology, Part B, Molecular and Developmental Evolution, volume 322, issue 4, pages 191-201, doi: 10.1002/jez.b.22567, PMID: 24665037; PMCID: PMC4277254, online at https://pubmed.ncbi.nlm.nih.gov/24665037/. [Dario Vargas, TC 8360, Summer 2020]

[17] Casuso, E. and J. E. Backman. (5 October 2019). "Analytical approach in the time evolution of rotation of galaxies" in SCIREA Journal of Physics, volume 4, issue 5, pp. 163-175.

[18] Cobb, John B., Jr. (1988). "Ecology, Science, and Religion: Toward a Postmodern Worldview" in The Reenchantment of Science: Postmodern Proposals, edited by David Ray Griffin. Albany, New York: State University of New York Press.

[19] Cobb, John B., Jr., editor. (2008). Back to Darwin: A Richer Account of Evolution. Grand Rapids, Michigan: William B. Eerdmans Publishing.

[20] Darwin, Charles. (1859). [Chapter I "Variation Under Domestication," and chapter II "Variation Under Nature," chapter III "Struggle for Existence," and chapter IV "Natural Selection; Or the Survival of the Fittest" ...] in On the Origin of Species By Means of Natural Selection; or, the Preservation of Favoured Races in the Struggle for Life. London: John Murray.

[21] Darwin, Charles (1871 [1874 new edition]). The Descent of Man, and Selection in Relation to Sex. London: John Murray.

[22] Denning, Kathryn. (2009). "Social Evolution: State of the Field," chapter 3 in Cosmos and Culture: Cultural Evolution in a Cosmic Context, edited by Steven J. Dick and Mark L. Lupisella. Washington, DC: NASA Office of External Relations.

[23] Dick, Steven J. and Mark Lupisella, editors. (2009). Cosmos and Culture: Cultural Evolution in a Cosmic Context. Washington, DC: National Aeronautics and Space Administration, Office of External Relations. 
[24] Grinnell, Frederick. (August 1975). "Cell Attachment to a Substratum and Cell Surface Proteases" in Archives of Biochemistry and Biophysics, volume 169, issue 2, pages 474482, online at https://doi.org/10.1016/0003-9861(75)90190-3. (Accessed 12 September 2021.)

[25] Haeckel, Ernst. (1868). Natürliche Schöpfungsgeschichte. Berlin: Georg Reimer. [Google Scholar]

[26] Haeckel, Ernst. (1874). Anthropogenie, 1st edition. Leipzig: Wilhelm Engelmann. [Google Scholar]

[27] Haeckel, Ernst. (1877). Anthropogenie, $3^{\text {rd }}$ edition. Leipzig: Wilhelm Engelmann. [Google Scholar]

[28] Hoyle, Fred. (1947). "On the Formation of Heavy Elements in Stars" in Proceedings of the Physical Society, volume 59, issue 6, pages 972-978.

[We are evolved star dust. We are made from heavy elements synthesized in previous generations of stars. See: "The Synthesis of the Elements from Hydrogen" (6 April 1946) by Fred Hoyle, "On the Condensation of the Planets" (13 April 1946) by Fred Hoyle, "The Chemical Composition of the Stars" (6 January 1947) by Fred Hoyle, "On the Formation of Heavy Elements in Stars" (1947) by Fred Hoyle, "Stellar Evolution and the Expanding Universe" (5 February 1949) by Fred Hoyle, "On Nuclear Reactions Occurring in Very Hot Stars. I. The Synthesis of Elements from Carbon to Nickel" (22 December 1953) by Fred Hoyle, "Origin of the Elements in Stars" (5 October 1956) by Fred Hoyle, William A. Fowler, E. Margaret Burbidge, and Geoffrey R. Burbidge, and "Synthesis of the Elements in Stars" (October 1957) by E. Margaret Burbidge, Geoffrey R. Burbidge, William A. Fowler, and Fred Hoyle $/ B^{2} F H$. The work signified by $B^{2} F H$ is so widely known because it was "a turning point in our knowledge of how the universe works" (Neil de Grasse Tyson and Donald Goldsmith 2004: 165).]

[29] Hoyle, Fred. (5 February 1949). "Stellar Evolution and the Expanding Universe" in Nature, volume 163, pages 196-198 [doi:10.1038/163196a0].

[30] Hoyle, Fred and N. Chandra Wickramasinghe. (1981). "Convergence to God" (chapter 9, pages 129-45) in Evolution from Space: A Theory of Cosmic Creationism. New York: Simon and Schuster.

[31] Jahr, Fritz. (1927). "Bio-Ethics: A Review of the Ethical Relationships of Humans to Animals and Plants." Kosmos 24: 4 [as cited in (Sass, December 2007)].

[32] Jenkins, Lillie R. (3 April 2021). "Black Apollo of Science: The Life of Ernest Everett Just - Summarizing Timeline, Sumitography and Concept Poster" (Alternative title: “E. E. 
Just: Administrative and Fund-seeking Pioneer"), online via SMU Scholar at https://scholar.smu.edu/theology research/27/. (Accessed 17 September 2021.)

[Abstract- "This two-part chronology is based on Kenneth R. Manning's biography, Black Apollo of Science: The Life of Ernest Everett Just (1983). Like other such timelines, this one details Just's life and pioneering research work. Additionally, and distinctively, this timetable lays out Just's pioneering fund-seeking and his work mentoring African American female co-researchers (Part 1). A sumitography featuring the United States Postal Service's postage stamp (1996) recognizes Just's innovative thinking in biology (Part 2). Following this logic, the author includes a proof-of-concept poster commending E.E. Just's work as a forward-thinking administrator. This timeline summarizes, chronicles, and aims to re-frame Just's two practices, fund-seeking and mentoring African American female scientists; showing that Just's administrative ideas were, arguably, as path-breaking and far-reaching as his research in marine biology. The concept poster is the first step toward advocacy for the United States Postal Service to issue a second Ernest Everett Just stamp to honor Just's leading edge administrative initiatives."]

[33] Just, Ernest Everett. (1919a). "The fertilization reaction in Echinarachnius parma: I. Cortical response of the egg to insemination" in The Biological Bulletin, 36, 1-10 [(Byrnes 2019)].

[34] Just, Ernest Everett. (1919b). "The fertilization reaction in Echinarachnius parma: II. The role of fertilizing in straight and cross fertilization" in The Biological Bulletin, 36, 11-38 [(Byrnes 2019)].

[35] Just, Ernest Everett. (1919c). "The fertilization reaction in Echinarachnius parma: III. The nature of the activation of the egg by butyric acid" in The Biological Bulletin, 36, 39-53 [(Byrnes 2019)].

[36] Just, Ernest Everett. (1920). “The fertilization-reaction in Echinarachnius parma: IV. A further analysis of the nature of butyric acid activation" in The Biological Bulletin, 39, 280-305 [(Byrnes 2019)].

[37] Just, Ernest Everett. (1921). "The susceptibility of the inseminated egg to hypotonic seawater. A contribution to the analysis of the fertilization-reaction" in Anatomical Record, 20, 225-227. [(Byrnes 2019)].

[38] Just, Ernest Everett. (1922a). "Initiation of development in the egg of arbacia: I. Effect of hypertonic sea-water in producing membrane separation, cleavage, and top-swimming plutei” in The Biological Bulletin, 43, 384-400. [(Byrnes 2019)]. 
[39] Just, Ernest Everett. (1922b). "Initiation of development in the egg of arbacia: II. Fertilization of eggs in various stages of artificially induced mitosis" in The Biological Bulletin, 43, 401-410. [(Byrnes 2019)].

[40] Just, Ernest Everett. (1922c). "Initiation of development in the egg of Arbacia: III. The effect of Arbacia blood on the fertilization-reaction" in The Biological Bulletin, 43 [(Just 1939b)].

[41] Just, Ernest Everett. (1932). "On the Origin of Mutations" in American Naturalist, 66, no. 702: 61-74.

[42] Just, Ernest Everett. (1933). "Cortical Cytoplasm and Evolution" in American Naturalist, 67 (708), 20-29.

[43] Just, Ernest Everett. (1937). “The significance of experimental parthenogenesis for the cell-biology of to-day" in Cytologia, Fujii Jubilaei, 540-550. [(Byrnes 2019)].

[44] Just, Ernest Everett. ([January] 1939a). The Biology of the Cell Surface. Philadelphia: P Blakiston's Son [New York: Garland Publishing, 1988 reprint].

[In his Preface, E. E. Just says: “... The book may be divided into three parts. Part I, comprising Introduction, Life and Experiment, Protoplasmic System, Ectoplasm, General Properties of the Ectoplasm and Water, though dealing primarily with the animal egg, embodies principles which concern the fundamental organization of any living thing. Part II, including the Fertilization-process, the Fertilization-reaction, Parthenogenesis, Celldivision and Cleavage and Differentiation, discusses in particular the problems that refer directly to animal eggs in their earliest stages of development. Part III, embracing chapters on the Chromosomes and Ectoplasm, Ectoplasm and Evolution, and Conclusion, has to do with more or less theoretical discussions. In particular, structure and function of the ectoplasm are emphasized, upon these my theory of the state of being alive is in large measure grounded. ... E E J Paris France November 1938" (Just 1939a: ix-x)]

[45] Just, Ernest Everett. ([June] 1939b). Basic Methods for Experiments on Eggs of Marine Animals. Philadelpia: P. Blakiston's Son.

[46] Just, Ernest Everett. (April 1940). "Unsolved Problems of General Biology" in Physiological Zoology, 13 (2): 123-42.

[47] Just, Ernest Everett and Hedwig Schnetzler Just. (October 1941 [July 2020]). The Origin of Man's Ethical Behavior.

[First titled "Ethics and the Struggle for Existence" in April 1941 (Kenneth R. Manning 1983: 327, $385 \mathrm{n} 12)$ ]. Originally unpublished book manuscript preserved at the Moorland-Spingarn Research Center at Howard University. A 251-page archival edition 
was transcribed and edited during $2018-2020$ by theological ethicist Theodore Walker Jr. and archival researcher Lillie R. Jenkins, with additional co-editing by Walker, Jenkins, and biochemist W. Malcolm Byrnes, in consultation with cell biologist Stuart Newman, historian of science Kenneth R. Manning, historian of religions Charles H. Long, and Moorland-Spingarn curator of manuscripts Joellen ElBashir, and published as The ORIGIN OF MAN'S ETHICAL BEHAVIOR (1941) by ERNEST EVERETT JUST \& HEDWIG SCHNETZLER JUST (4 July 2020) in paperback (\$11.00) and Kindle (99 cent) formats via Amazon.com.] Also, see Annotated Index and Bibliography to the 251-page archival edition of The ORIGIN OF MAN'S ETHICAL BEHAVIOR (1941) by Ernest Everett Just \& Hedwig A. Schnetzler Just: Plus historical notes and manifest (Amazon, 25 July 2020) by Theodore Walker Jr.]

[48] King, Nicole. (September 2004). "The Unicellular Ancestry of Animal Development” in Developmental Cell, volume 7, pages 313-325, online at https://www.cell.com/developmental-cell/pdf/S1534-5807(04)00288-6.pdf

[49] Kropotkin, Peter [Petr Alekseyevich Kropotkin]. (1902). Mutual Aid: A Factor of Evolution, edited by Charles Aldarondo. Kindle Edition: Amazon Digital Services, based upon print edition ISBN 1502589664; CreateSpace Independent Publishing Platform, 2014.

[50] Lin, Haifan. (19 May 2020). "Stem Cells and Regenerative Medicine: Progress and Prospect," a Yale University Stem Cell Center Lecture, posted on YouTube at https://www.youtube.com/watch?v=u79 3pQJVDk. (Accessed 17 September 2021)

[51] Long, Charles H. (1963). "Creation from Chaos and from the Cosmic Egg" (chapter 3) in Alpha: The Myths of Creation. Chico, California: Scholars Press.

[52] Lovelock, James E. (1972). "Gaia as seen through the atmosphere" in Atmospheric Environment, volume 6, issue 8, pages 579-580 [doi:10.1016/0004-6981(72)90076-5.

[53] Lovelock, James E. and Lynn Margulis. (1974). "Atmospheric homeostasis by and for the biosphere: the gaia hypothesis," Tellus, 26:1-2, 2-10, DOI: $10.3402 /$ tellusa.v26i1-2.9731

[54] Mangal, Mélina; illustrations by Luisa Uribe. (2018). Vast Wonder of the World: Biologist Ernest Everett Just. (LC classification - Juvenile literature [with colorful graphic illustrations and scholarly notes]). Minneapolis: Millbrook Press.

[55] Manning, Kenneth R. (1983). Black Apollo of Science: The Life of Ernest Everett Just. Oxford: Oxford University Press.

[56] Manning, Kenneth R. (16 July 2009). "Reflections on E. E. Just, Black Apollo of Science, and the Experiences of African American Scientists" in Molecular Reproduction and 
Development, 76 (10): 897-902 [https://doi.org/10.1002/mrd.21087]. (Accessed 17 September 2021.)

[Abstract - "The text below is a transcript of the keynote address Kenneth Manning gave at the symposium honoring E. E. Just that was held on the campus of Howard University on November 21, 2008. In his talk, Manning reflects on his experiences researching and writing Black Apollo of Science: The Life of Ernest Everett Just, his prize-winning biography published in 1983. In the process, he retells the fascinating story of the life of E. E. Just. Manning also discusses a number of other topics, including Just's legacy, the role of African Americans in science, and the importance of having minority representation on college campuses." (Transcribed by: W. Malcolm Byrnes, Department of Biochemistry and Molecular Biology, Howard University College of Medicine, Washington, DC.) Mol. Reprod. Dev. 76: 897-902, 2009. (C) 2009 Wiley-Liss, Inc.]

[57] Margulis, Lynn. (1981). Symbiosis in Cell Evolution: Life and Its Environment on the Early Earth. San Francisco: W. H. Freeman.

[58] Margulis, Lynn. (c1993). Symbiosis in Cell Evolution: Microbial Communities in the Archean and Proterozoic Eons, $2^{\text {nd }}$ edition. New York: Freeman.

[59] Marlow, Jeffrey and Rogier Braakman. (November 2018). "Team Players: Long thought mostly to compete with one another, microbes turn out to form partnerships that rule the planet" in Scientific American, volume 319, number 5, pages 32-39.

[60] McCulloch, Ernest, and James Till. (1 October 2005). "Perspectives on the Properties of Stem Cells" in Nature Medicine, 11, 1026-1028, https://doi.org/10.1038/nm1005-1026. (Accessed 12 September 2021.)

[61] Potter, Van Rensselaer. (1971). Bioethics: Bridge to the Future, edited by Carl P Swanson. Englewood Cliffs, New Jersey: Prentice-Hall Biological Science Series.

[62] Potter, Van Rensselaer. [University of Wisconsin] (1984). "Bioethics and the Human Prospect" (pages 124-137) in The Culture of Biomedicine: Studies in Science and Culture, volume 1, edited by D. Heyward Brock. Newark: University of Delaware Press. [Here Potter calls for "Evolutionary Bioethics" (page 135).]

[63] Potter, Van Rensselaer. (1988). Global Bioethics: Building on the Leopold Legacy. East Lansing, Michigan: Michigan State University Press.

[64] Ramalho-Santos, Miguel, and Holger Willenbring. (7 June 2007). “On the Origin of the Term 'Stem Cell'” in Cell Stem Cell, volume 1, issue 1, pages 35-28, online at https://doi.org/10.1016/j.stem.2007.05.013. (Accessed 13 September 2021.) 
[Concerning Ernst Haeckel's use of the term "Stammzelle" to refer first to our common unicellular ancestor, then to both unicellular ancestor and fertilized egg cell: In "On the Origin of the Term 'Stem Cell'” (7 June 2007) Miguel Ramalho-Santos and Holger Willenbring say: "The term stem cell appears in the scientific literature as early as 1868 in the works of the eminent German biologist Ernst Haeckel (Haeckel, 1868). Haeckel, a major supporter of Darwin's theory of evolution, drew a number of phylogenetic trees to represent the evolution of organisms by descent from common ancestors and called these trees "Stammbäume" (German for family trees or "stem trees"). In this context, Haeckel used the term "Stammzelle" (German for stem cell) to describe the ancestor unicellular organism from which he presumed all multicellular organisms evolved (Haeckel, 1868, Haeckel, 1874). In the revised 3rd edition of his book Anthropogenie (Haeckel, 1877), Haeckel made one of his characteristic leaps from evolution (phylogeny) to embryology (ontogeny) and proposed that the fertilized egg also be called stem cell. That is, Haeckel used the term stem cell in two senses: as the unicellular ancestor of all multicellular organisms and as the fertilized egg that gives rise to all cells of the organism."]

[65] Sass, Hans-Martin. (December 2007). "Fritz Jahr's 1927 Concept of Bioethics" in Kennedy Institute of Ethics Journal, volume 17, number 4, pp. 279-295 [https://pubmed.ncbi.nlm.nih.gov/18363267/] (Accessed 17 September 2021.)

[66] Schroeder, Doris. "Evolutionary Ethics" in The Internet Encyclopedia of Philosophy, (IEP) (ISSN 2161-0002), online at https://iep.utm.edu/evol-eth/ (Accessed 12 September 2021)

[67] Shah, Hiral, Gautam Dey and Omaya Dudin. (5 January 2021). "Tracing the History of Animal Origins" is a review of the posted on 10 November 2020 preprint (not yet peer reviewed) of "The Single-Celled Ancestors of Animals: A History of Hypotheses" (5 November 2020) by Thibaut Brunet and Nicole King, in preLights, Preprint Highlights Selected by the Biological Community, online at https://prelights.biologists.com/highlights/the-single-celled-ancestors-of-animals-ahistory-of-hypotheses/. (Accessed 18 September 2021.)

[68] Takahashi Kazutoshi, and Shinya Yamanaka. (25 August 2006). "Induction of pluripotent stem cells from mouse embryonic and adult fibroblast cultures by defined factors" in Cell, volume 126, pages 663-676, online at https://doi.org/10.1016/j.cell.2006.07.024. (Accessed 12 September 2021.) ["Summary - Differentiated cells can be reprogrammed to an embryonic-like state by transfer of nuclear contents into oocytes or by fusion with embryonic stem (ES) cells. Little is known about factors that induce this reprogramming. 
Here, we demonstrate induction of pluripotent stem cells from mouse embryonic or adult fibroblasts by introducing four factors, Oct3/4, Sox2, c-Myc, and Klf4, under ES cell culture conditions. Unexpectedly, Nanog was dispensable. These cells, which we designated iPS (induced pluripotent stem) cells, exhibit the morphology and growth properties of ES cells and express ES cell marker genes. Subcutaneous transplantation of iPS cells into nude mice resulted in tumors containing a variety of tissues from all three germ layers. Following injection into blastocysts, iPS cells contributed to mouse embryonic development. These data demonstrate that pluripotent stem cells can be directly generated from fibroblast cultures by the addition of only a few defined factors."]

[69] Tyson, Neil de Grasse and Donald Goldsmith. (2004). Origins: Fourteen Billion Years of Cosmic Evolution. New York; London: W. W. Norton.

[70] Walker, Theodore, Jr. (January 2020). "The Bioethical Significance of 'The Origin of Man's Ethical Behavior' (October 1941, unpublished) by Ernest Everett Just and Hedwig Anna Schnetzler Just" in the Journal of the South Carolina Academy of Science, volume 18, issue 1, article 4, online at https://scholarcommons.sc.edu/jscas/vol18/iss 1/4. (Accessed 17 September 2021.)

[Abstract - "E. E. Just (1883-1941) is an acknowledged "pioneer" in cell biology, and he is perhaps the pioneer in study of egg cell fertilization. Here we discover that Just also made pioneering contributions to general biology and evolutionary bioethics. Within Just's published contributions to observational cell biology, there are substantial fragments of his theory of ethical behavior, a theory with roots in cell biology. In addition to such previously available fragments, Just's fully developed theory is now available. This recently discovered unpublished book-length manuscript argues for the biological origins of ethical behavior (evolving from cells to humans, within a living environment, and subject to the "law of environmental dependence"). Contemporary research is starting to catch up to Just. In evolutionary bioethics, Just is the pioneer.”]

[71] Walker, Theodore, Jr. (February 2020). "Ernest Everett Just (1883-1941): Hero in Cell Biology and in Evolutionary Bioethics" in the Meharry Medical College Journal of Health Care for the Poor and Underserved, volume 31, number 1, pages 4-10. | Johns Hopkins University Press. Project MUSE, doi:10.1353/hpu.2020.0002, online at http://muse.jhu.edu/article/747768 and at https://pubmed.ncbi.nlm.nih.gov/32037311/. (Accessed 17 September 2021.)

[Abstract- "Ernest Everett Just is celebrated for his contributions to cell biology. Among other firsts, he was first to describe the "wave of negativity" spreading around an egg cell 
from the entrance point of the fertilizing spermatozoon. His accomplishments in biology are celebrated in Black Apollo of Science (1983) by Kenneth Manning, and by a 1996 Black Heritage postage stamp. What is not yet widely appreciated, however, is that Just connected evolutionary biology to ethical behavior $(1933,1939,1940)$. He was probably the first cell biologist to argue that human ethical behavior evolved from our very most primitive cellular origins. Today, Just's contributions to evolutionary bioethics, including "the law of environmental dependence," can be better appreciated because his unpublished book-length manuscript, "The Origin of Man's Ethical Behavior" has been preserved at Howard University's Moorland-Spingarn Research Center.”] [Here is said: “... no doubt, there will someday be a video drama or movie about Just. No doubt, too, that video will include Just's internment (August 1940) and dramatic escape (early September 1940) from Nazi-occupied France (with rescue help from the well-connected German family of his second wife, Hedwig Schnetzler Just), his return to Howard University (late September 1940), and his death at age 58 from pancreatic cancer on 27 October 1941.”]

[72] Walker, Theodore, Jr. (29 April 2020). "Interdisciplinary Convergences with Biology and Ethics via Cell Biologist Ernest Everett Just and Astrobiologist Sir Fred Hoyle" (chapter one, pages 11-35) in Panentheism and Panpsychism: Philosophy of Religion Meets Philosophy of Mind Series: Innsbruck Studies in Philosophy of Religion, Volume: 2, edited by Godehard Brüntrup, Benedikt Paul Göcke and Ludwig Jaskolla. Leiden, Netherlands: Mentis Verlag | Brill, 2020. Online at https://brill.com/view/title/55646. (Accessed 17 September 2021.)

[73] Wickramasinghe, Chandra, editor. (2015). Vindication of Cosmic Biology: Tribute to Sir Fred Hoyle (1915-2001). New Jersey: World Scientific.

[74] Williams, Katelyn M. with Bryan A. Wilson, Wendi G. O'Connor, and Monte S. Willis. (18 July 2013). "Ernest Everett Just, PhD: Pioneer in Ecological Developmental (EcoDevo) Biology" in the Journal of the South Carolina Academy of Science, volume 11, issue 1 , article 5, online at https://scholarcommons.sc.edu/jscas/vol11/iss1/5/. (Accessed 17 September 2021.)

[Abstract- "Ernest Everett Just, a pioneering American biologist, discovered the fundamental role of the environment in the development of embryos. His work led to the creation of the area of biology known as ecological developmental (Eco-Devo) biology. However, both his work and the context of his scientific contributions are not widely known. His work covered a diversity of fields of biology, including marine biology, 
cytology, and parthogenesis (asexual reproduction where growth and development of embryos occur without fertilization). His findings provided important concepts in developmental biology that are used to this day. Specifically, he demonstrated the importance of the cellular cytoplasm and ectoplasm, in addition to the nucleus, in determining how development occurs in embryos. His worked was unique for its use of in vivo conditions using a variety of marine organisms. His publications on the "Basic Methods for Experiments on Eggs of Marine Mammals" in 1922 [1939b] and "The Biology of the Cell Surface" in 1939 are still regarded as two of the most comprehensive reviews in cell biology. In this manuscript we present Dr. Just's childhood in Charleston, SC, unlikely attendance and success at Dartmouth College, and his groundbreaking work, which was developed at the Marine Biological Laboratory (MBL) at Woods Hole, Europe, and Howard University."']

[75] Wilson, Edmund B. (1896). The Cell in Development and Inheritance. New York: Macmillan.

[76] Wilson, Edward O. (1975). Sociobiology: The New Synthesis. Cambridge, Massachusetts: Belknap Press of Harvard University Press.

[77] Yamanaka, Shinya. (14 June 2012). "Induced Pluripotent Stem Cells: Past, Present, and Future" in Cell Stem Cell, volume 10, issue 6, pp. 678-684, online at https://doi.org/10.1016/j.stem.2012.05.005 (Accessed 12 September 2021.) 